\title{
INVESTIGATIONS ON EXHAUST EMISSIONS OF HIGH GRADE LOW HEAT REJECTION DIESELENGINE WITH COTTON SEED BIODIESEL
}

\author{
N. Venkateswara Rao \\ Department of Mechanical Engineering, \\ Chaitanya Bharathi Institute of Technology, Hyderabad, Telangana State, India \\ M.V.S. Murali Krishna* \\ Department of Mechanical Engineering, \\ Chaitanya Bharathi Institute of Technology, Hyderabad, Telangana State, India \\ D. Srikanth \\ Department of Mechanical Engineering, \\ Sagar Group of Educational Institutions, Chevella, \\ Hyderabad, Telangana State, India \\ *Corresponding Author
}

\begin{abstract}
Biodiesels derived from vegetable oils present a very promising alternative for diesel fuel, since they have numerous advantages compared to fossil fuels. They are renewable, biodegradable, provide energy security and foreign exchange savings besides addressing environmental concerns and socio-economic issues. However drawbacks associated with biodiesel of high viscosity and low volatility which cause combustion problems in compression ignition engines, call for low heat rejection (LHR) engine. LHR engines have significant characteristics of higher operating temperature, maximum heat release, and ability to handle low calorific value fuel. Investigations were carried out to determine exhaust emissions with LHR engine and conventional engine (CE) with crude cotton seed biodiesel. LHR e $n g$ ine consisted of an air gap insulated piston, an air gap insulated liner and ceramic coated cylinder head with different operating conditions of normal temperature and preheated temperature cottonseed biodiesel with varied injector opening pressure. Nozzle testing apparatus was used to increase injector opening pressure. Particulate emissions and oxides of nitrogen were determined with sophisticated analyzers at full load operation of the engine. LHR engine reduced pollutants at higher injector opening pressure at preheated temperature of biodiesel in comparison with neat diesel operation on CE.
\end{abstract}

Keywords: Biodiesel; LHR engine, Fuel performance; Exhaust emissions. 
Cite this Article: N. Venkateswara Rao, M.V.S. Murali Krishna and D. Srikanth, Investigations on Exhaust Emissions of High Grade Low Heat Rejection Diesel Engine with Cotton Seed Biodiesel, International Journal of Mechanical Engineering and Technology (IJMET), 12(5), 2021, pp. 1-10. https://iaeme.com/Home/issue/IJMET?Volume=12\&Issue $=5$

\section{INTRODUCTION}

Fossil fuels are limited resources; hence, search for renewable fuels is becoming more and more prominent for ensuring energy security and environmental protection. It has been found that the vegetable oils are promising substitute for diesel fuel, because of their properties are comparable to those of diesel fuel. They are renewable and can be easily produced. When Rudolph Diesel, first invented the diesel engine, about a century ago, he demonstrated the principle by employing peanut oil. He hinted that vegetable oil would be the future fuel in diesel engine [1]. Several researchers experimented the use of vegetable oils as fuel on conventional engines (CE) and reported that the performance was poor, citing the problems of high viscosity, low volatility and their polyunsaturated character. It caused the problems of piston ring sticking, injector and combustion chamber deposits, fuel system deposits, reduced power, reduced fuel economy and increased exhaust emissions [1-5].

The problems of crude vegetable oils can be solved to some extent, if these oils are chemically modified (esterified) to biodiesel. Studies were made with biodiesel on CE [6-10]. They reported from their investigations that biodiesel operation showed comparable thermal efficiency, decreased particulate emissions and increased nitrogen oxide $\left(\mathrm{NO}_{\mathrm{x}}\right)$ levels, when compared with mineral diesel operation.

Experiments were conducted on preheated vegetable oils in order to equalize their viscosity to that of mineral diesel may ease the problems of injection process [11-13]. Investigations were carried out on engine with preheated vegetable oils. They reported that preheated vegetable oils marginally increased thermal efficiency, decreased particulate matter emissions and $\mathrm{NO}_{\mathrm{x}}$ levels, when compared with normal biodiesel.

Increased injector opening pressure may also result in efficient combustion in compression ignition engine [14-15]. It has a significance effect on performance and formation of pollutants inside the direct injection diesel engine combustion. Experiments were conducted on engine with biodiesel with increased injector opening pressure. They reported that performance of the engine was improved, particulate emissions were reduced and $\mathrm{NO}_{\mathrm{x}}$ levels were increased marginally with an increase of injector opening pressure.

The drawbacks associated with biodiesel (high viscosity and low volatility) call for hot combustion chamber, provided by low heat rejection (LHR) combustion chamber. The concept of the engine with LHR combustion chamber is reduce heat loss to thecoolant with provision of thermal resistance in the path of heat flow to the coolant. Three approaches that are being pursued todecrease heat rejection are (1) Coating with low thermal conductivity materials on crown of the piston, inner portion of the liner and cylinder head (low grade LHR combustion chamber); (2) air gap insulation where air gap is provided in the piston and other components with low-thermal conductivity materials like superni (an alloy of nickel),cast iron and mild steel (medium grade LHR combustion chamber); and (3).high grade LHR engine contains air gap insulation and ceramic coated components.

Experiments were conducted on engine with high grade LHR combustion chamber with biodiesel. It consisted of an air gap $(3 \mathrm{~mm})$ insulation in piston as well as in liner and ceramic coated cylinder head. The engine was fuelled with biodiesel with varied injector opening pressure and injection timing [16-22]. They reported from their investigations, that engine with 
LHR combustion chamber at an optimum injection timing of $28^{\circ} \mathrm{bTDC}$ with biodiesel increased brake thermal efficiency by 10-12\%, at full load operation-decreased particulate emissions by 45-50\% and increased $\mathrm{NO}_{\mathrm{x}}$ levels, by 45-50\% when compared with neat diesel operation on $\mathrm{CE}$ at $27^{\circ} \mathrm{bTDC}$. Experiments were conducted with engine having different combustion chambers and comparative studies were made among LR-1, LHR-2 and LHR-3 engines with neat diesel operation with varied injector opening pressure and injection timing. [23-24]. LHR3 engine significantly reduced particulate emissions and drastically increased oxides of nitrogen in comparison with $\mathrm{CE}$ with neat diesel operation at recommended injection timing.

The present paper attempted to determine the performance of the engine with high grade LHR combustion chamber. It contained an air gap $(3.2 \mathrm{~mm})$ insulated piston, an air gap (3.2 $\mathrm{mm}$ ) insulated liner and ceramic coated cylinder head with cotton seed biodiesel with different operating conditions with varied injection timing and injector opening pressure. Results were compared with CE with biodiesel and also with diesel at similar operating conditions.

\section{MATERIALS AND METHODS}

Cottonseeds have approximately $18 \%(\mathrm{w} / \mathrm{w})$ oil content. India's cottonseed production is estimated to be around $35 \%$ of its cotton output (approximately 4.5 millionmetric tons). Approximately 0.30 million metric ton cottonseed oil is produced in Indiaand it is an attractive biodiesel feedstock [5]

\subsection{Preparation of Biodiesel}

The chemical conversion of esterification reduced viscosity four fold. Crude cotton seed oil contains up to $70 \%$ (wt.) free fatty acids. The methyl ester was produced by chemically reacting crude cotton seed oil with methanol in the presence of a catalyst $(\mathrm{KOH})$. A two-stage process was used for the esterification of the crude cotton seed oil [5]. The first stage (acid-catalyzed) of the process is to reduce the free fatty acids (FFA) content in cotton seed oil by esterification with methanol (99\% pure) and acid catalyst (sulfuric acid-98\% pure) in one hour time of reaction at $55^{\circ} \mathrm{C}$. Molar ratio of cotton seed oil to methanol was $9: 1$ and $0.75 \%$ catalyst $(\mathrm{w} / \mathrm{w})$. In the second stage (alkali-catalyzed), the triglyceride portion of the cotton seed oil reacts with methanol and base catalyst (sodium hydroxide-99\% pure), in one hour time of reaction at $65^{\circ} \mathrm{C}$, to form methyl ester (biodiesel) and glycerol. To remove un-reacted methoxide present in raw methyl ester, it is purified by the process of water washing with air-bubbling. The properties of the Test Fuels used in the experiment were presented in Table-1. [5].

Table 1 Properties of test fuels [5]

\begin{tabular}{|l|c|c|c|c|}
\hline \multicolumn{1}{|c|}{$\begin{array}{c}\text { Propert } \\
\mathbf{y}\end{array}$} & Units & Diesel (DF) & Biodiesel(BD) & ASTM Standard \\
\hline Carbon Chain & -- & $\mathrm{C}_{8}-\mathrm{C}_{28}$ & $\mathrm{C}_{16}-\mathrm{C}_{24}$ & --- \\
\hline Cetane Number & - & 51 & 56 & ASTM D 613 \\
\hline Specific Gravity at $15^{\circ} \mathrm{C}$ & - & 0.8275 & 0.8673 & ASTM D 4809 \\
\hline Bulk Modulus at $15^{\circ} \mathrm{C}$ & $\mathrm{MPa}$ & 1408.3 & 1564 & ASTM D 6793 \\
\hline Kinematic Viscosity @ $40^{\circ} \mathrm{C}$ & $\mathrm{cSt}$ & 2.5 & 5.44 & ASTM D 445 \\
\hline Air Fuel Ratio & -- & 14.86 & 13.8 & ASTM D93 \\
\hline $\begin{array}{l}\text { Flash Point (Pensky Marten's } \\
\text { Closed Cup) }\end{array}$ & ${ }^{\circ} \mathrm{C}$ & 120 & 144 & ASTM D 6371 \\
\hline Cold Filter Plugging Point & ${ }^{\circ} \mathrm{C}$ & $\begin{array}{c}\text { Winter } 6^{\circ} \mathrm{C} \\
\text { Summer } 18^{\circ} \mathrm{C}\end{array}$ & $3^{\circ} \mathrm{C}$ & ASTM D 97 \\
\hline Pour Point & ${ }^{\mathrm{O}} \mathrm{C}$ & $\begin{array}{c}\text { Winter } 3^{\circ} \mathrm{C} \\
\text { Summer } 15^{\circ} \mathrm{C}\end{array}$ & $0^{\circ} \mathrm{C}$ & ASTM D5453 \\
\hline Sulfur & $(\mathrm{mg} / \mathrm{kg}, \mathrm{max})$ & 50 & 42 & ASTM D 7314 \\
\hline Low Calorific Value & $\mathrm{MJ} / \mathrm{kg}$ & 42.0 & 39.9 & -- \\
\hline Oxygen Content & $\%$ & 0.3 & 11 & \\
\hline
\end{tabular}




\subsection{Engine with LHR combustion chamber}

1.Piston crown with threads, 2. Superni gasket, 3. Air gap in piston, 4. Body of piston, 5 . Ceramic coating on inside portion of cylinderhead, 6. Cylinder head, 7.Superni insert with threads, 8.Air gap in liner, 9.Liner
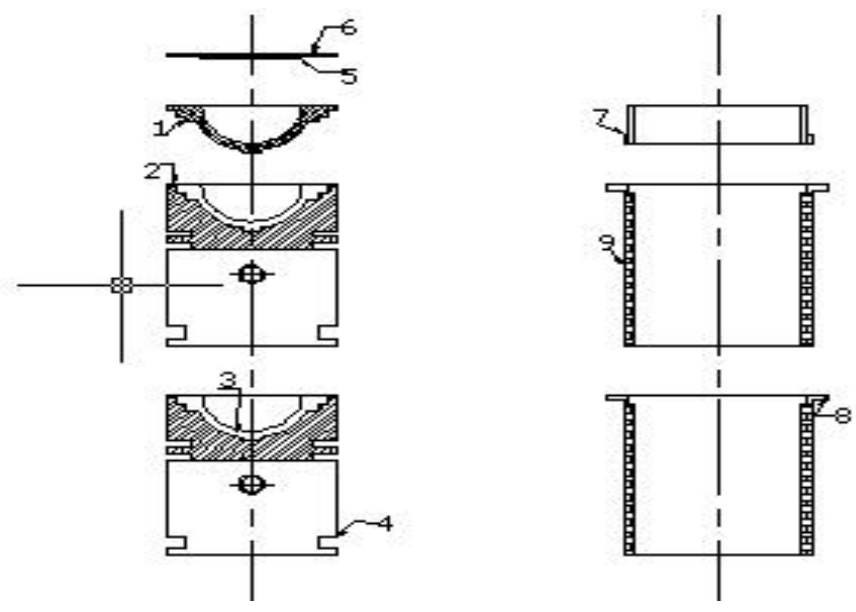

Figure 1 Assembly details of air gap insulated piston, air gap insulated liner and ceramic coated cylinder head

Engine with LHR combustion chamber contained a two-part piston ; the top crown made of superni was screwed to aluminium body of the piston, providing an air gap $(3.2 \mathrm{~mm})$ in between the crown and the body of the piston by placing a superni gasket in between the body and crown of the piston. A superni insert was screwed to the top portion of the liner in such a manner that an air gap of $3.2 \mathrm{~mm}$ was maintained between the insert and the liner body. At 500 ${ }^{\circ} \mathrm{C}$ the thermal conductivity of superni and air are 20.92 and $0.057 \mathrm{~W} / \mathrm{m}-\mathrm{K}$. Partially stabilized zirconium (PSZ) of thickness 500 microns was coated by means of plasma coating technique. The combination of low thermal conductivity materials of air, superni and PSZ provide sufficient insulation for heat flow to the coolant, thus resulting in LHR combustion chamber.

\subsection{Experimental set-up}

The schematic diagram of the experimental setup used for the investigations on the engine with LHR combustion chamber with cotton seed biodiesel is shown in Fig.2. Specifications of Test engine are given in Table 2. The engine was coupled with an electric dynamometer (Kirloskar), which was loaded by a loading rheostat. The fuel rate was measured by Burette. The accuracy of brake thermal efficiency obtained is $\pm 2 \%$. Provision was made for preheating of biodiesel to the required levels $\left(90^{\circ} \mathrm{C}\right)$ so that its viscosity was equalized to that of diesel fuel at room temperature. Air- consumption of the engine was obtained with an aid of air box, orifice flow meter and U-tube water manometer assembly. The naturally aspirated engine was provided with water-cooling system in which outlet temperature of water was maintained at $80^{\circ} \mathrm{C}$ by adjusting the water flow rate. The water flow rate was measured by means of analogue water flow meter, with accuracy of measurement of $\pm 1 \%$. 


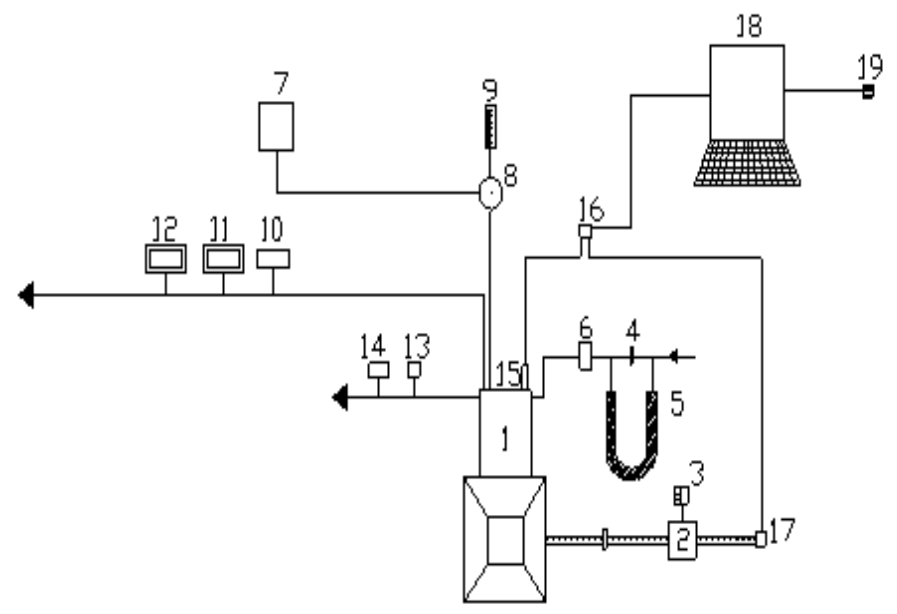

1.Engine, 2.Electical Dynamometer, 3.Load Box, 4.Orifice flow meter, 5.U-tube water manometer, 6.Air box, 7.Fuel tank, 8, Pre-heater, 9.Burette, 10. Exhaust gas temperature indicator, 11.AVL Smoke meter, 12.Netel Chromatograph NOx Analyzer, 13.Outlet jacket water temperature indicator, 14. Outlet-jacket water flow meter, 15.Piezo-electric pressure transducer, 16.Console, 17.TDC encoder, 18.Pentium Personal Computer and 19. Printer.

Figure 2 Schematic diagram of experimental set-up

Engine oil was provided with a pressure feed system. No temperature control was incorporated, for measuring the lube oil temperature. Copper shims of suitable size were provided in between the pump body and the engine frame, to vary the injection timing. Injector opening pressure was changed from 190 bar to 270 bar using nozzle testing device.

Table.2 Specifications of Test Engine

\begin{tabular}{|l|l|}
\hline \multicolumn{1}{|c|}{ Description } & \multicolumn{1}{c|}{ Specification } \\
\hline Engine make and model & Kirloskar ( India) AV1 \\
\hline Maximum power output at a speed of $1500 \mathrm{rpm}$ & $3.68 \mathrm{~kW}$ \\
\hline Number of cylinders $\times$ cylinder position $\times$ stroke & One $\times$ Vertical position $\times$ four-stroke \\
\hline Bore $\times$ stroke & $80 \mathrm{~mm} \times 110 \mathrm{~mm}$ \\
\hline Engine Displacement & $553 \mathrm{cc}$ \\
\hline Method of cooling & Water cooled \\
\hline Rated speed ( constant) & $1500 \mathrm{rpm}$ \\
\hline Fuel injection system & In-line and direct injection \\
\hline Compression ratio & $16: 1$ \\
\hline BMEP @ 1500 rpm at full load & 5.31 bar \\
\hline $\begin{array}{l}\text { Manufacturer's recommended injection timing and } \\
\text { injectoropening pressure }\end{array}$ & $27^{\circ} \mathrm{bTDC} \times 190$ bar \\
\hline Number of holes of injector and size & Three $\times 0.25 \mathrm{~mm}$ \\
\hline Type of combustion chamber & Direct injection type \\
\hline
\end{tabular}

The maximum injector opening pressure was restricted to 270 bar due to practical difficulties involved. Coolant water jacket inlet temperature, outlet water jacket temperature and exhaust gas temperature were measured by employing iron and iron- constantan thermocouples connected to analogue temperature indicators. The accuracies of analogue temperature indicators are $\pm 1 \%$. Exhaust emissions of particulate matter and nitrogen oxides $\left(\mathrm{NO}_{\mathrm{x}}\right)$ were recorded by smoke opacity meter (AVL India, 437) and $\mathrm{NO}_{\mathrm{x}}$ Analyzer (Netel India; $4000 \mathrm{VM})$ at full load operation of the engine.

\subsection{Test Conditions}

Test fuels used in the experiment were neat diesel and biodiesel. Various configurations of the engine were conventional engine and engine with LHR combustion chamber. Test fuels used 
in the experiment were neat diesel and biodiesel. Various configurations of the engine were conventional engine and engine with LHR combustion chamber. Different operating conditions of the biodiesel were normal temperature and preheated temperature. Different injector opening pressures attempted in this experiment were 190 and 270 bar. Each test was repeated twelve times to ensure the reproducibility of data according to error analysis (Minimum number of trials must be not less than ten).

\section{RESULTS AND DISCUSSION}

Particulate emissions and oxides of nitrogen are the exhaust emissions from diesel engine and inhaling of these emissions cause health hazards and also they cause environmental impact. [25-27]. Figure.3 presents bar charts showing the variation of particulate emissions with different versions of the engine with different injector opening pressures. Biodiesel with both versions of the engine showed lower particulate emissions than neaet diesel operation. Earlier studies have suggested following reasons for relatively lower particulate emissions with biodiesel (a) presence of fuel oxygen, (b) increase in the $\mathrm{O} / \mathrm{C}$ ratio at the flame lift-off length, [The $\mathrm{O} / \mathrm{C}(\mathrm{w} / \mathrm{w})$ ratio here refers to the total oxygen (air and fuel) $(\mathrm{w} / \mathrm{w})$ in the combustible mixture to total carbon in the fuel. For biodiesel, carbon and oxygen content in the fuel was obtained from GC analysis. Oxygen originates from air and fuel (biodiesel) both. For diesel, the standard formula given in the published literature has been used to calculate the $\mathrm{O} / \mathrm{C}$ ratio [17]. (c) longer flame liftoff length due to higher injection velocity obtained with biodiesel, and (d) superior fuel atomization due to higher injection pressures with biodiesel [5]. From Fig.3, it is observed that engine with LHR combustion chamber with biodiesel operation decreased particulate emissions at full load by $33 \%$ at $27^{\circ}$ bTDC when compared diesel operation on engine with LHR combustion chamber at $27^{\circ} \mathrm{bTDC}$. Improved combustion of higher cetane value biodiesel in the hot environment provided by engine with LHR combustion chamber might have reduced particulate emissions with test fuels. Fig. 3 indicates that engine with LHR combustion chamber with biodiesel decreased particulate emissions at full load operation by $11 \%$ at $27^{\circ} \mathrm{bTDC}$, in comparison with CE at $27^{\circ} \mathrm{bTDC}$. Improved combustion of biodiesel with improved oxygen- fuel ratios might have reduced particulate emissions in the LHR version of the combustion chamber. Particulate emissions reduced with an increase of an injector opening pressure with both versions of the engine with test fuels. This is due to improved spray characteristics of the fuel with increased injector opening pressure.

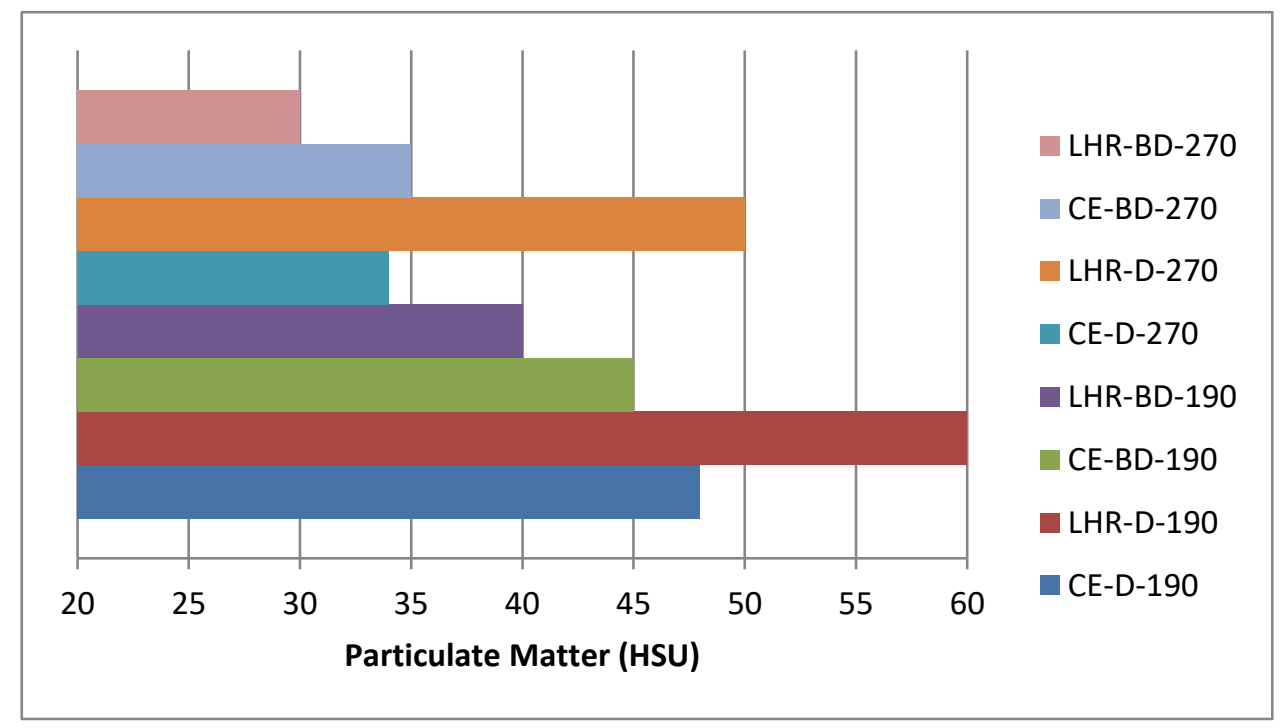

Figure 3. Variation of particulate emissions with injector opening pressure 
The temperature and availability of oxygen are the reasons for the formation of $\mathrm{NO}_{\mathrm{x}}$ levels. Figure.4 presents bar charts showing the variation of nitrogen oxide levels with different versions of the engine with different injector opening pressures.

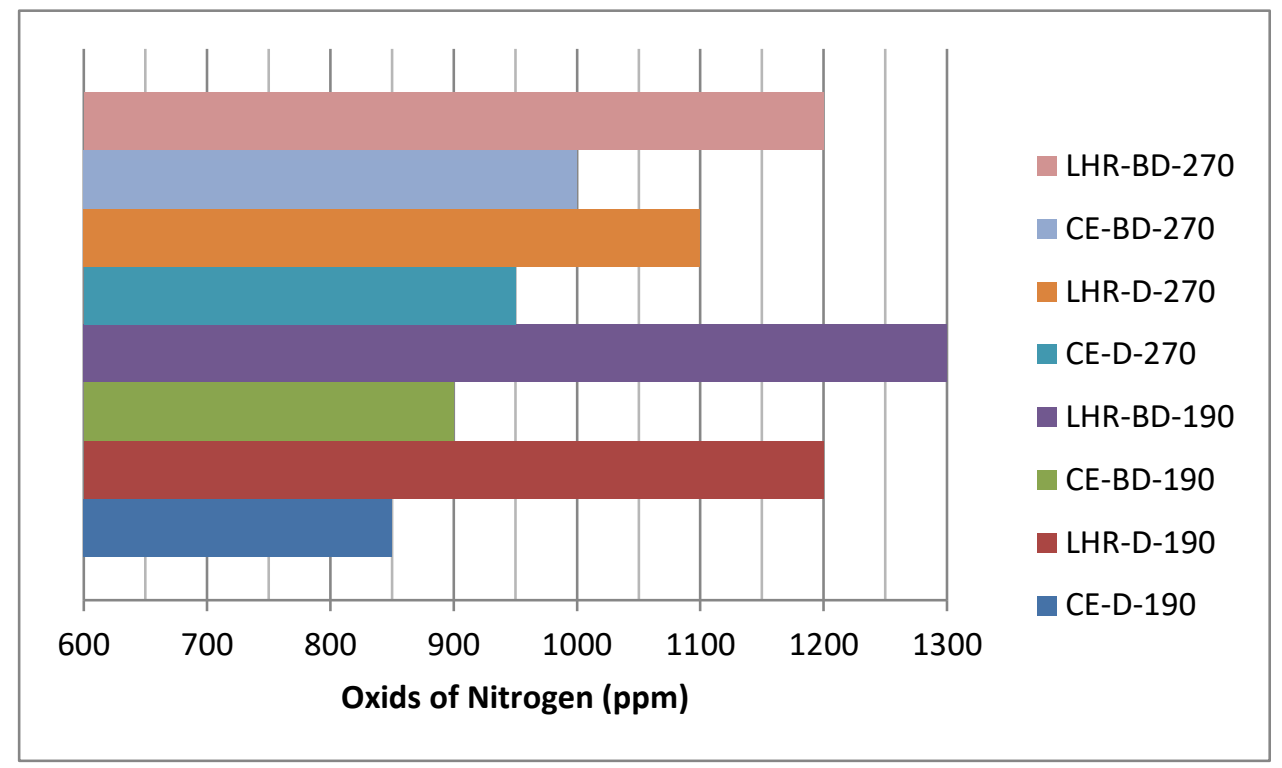

Figure 4. Variation of nitrogen oxide levels with injector opening pressure

Biodiesel operation increased NOx levels with both versions of the engine, in comparison with neat diesel operation on $\mathrm{CE}$. The increase in $\mathrm{NO}_{\mathrm{x}}$ emission might be an inherent characteristic of biodiesel due to the presence of long chain mono- unsaturated fatty acids (MUFA) and of poly-unsaturated fatty acids (PUFA). [28] [29]. resence of oxygen (10\%) in the methyl ester, which leads to improvement in oxidation of the nitrogen available during combustion. This will raise the combustion bulk temperature responsible for thermal $\mathrm{NO}_{\mathrm{x}}$ formation. From Fig.4, it is observed that $\mathrm{CE}$ with biodiesel operation increased $\mathrm{NO}_{\mathrm{x}}$ levels at full load by $6 \%$ at $27^{\circ} \mathrm{bTDC}$, when compared with diesel operation on CE at $27^{\circ} \mathrm{bTDC}$.

From Fig.4. it is observed that NOx levels at full load operation on engine with LHR combustion chamber with biodiesel increased by $8 \%$ at $27^{\circ} \mathrm{bTDC}$, when compared diesel operation on engine with LHR combustion chamber at $27^{\circ} \mathrm{bTDC}$. Higher cetane value of biodiesel might have improved $\mathrm{NO}_{\mathrm{x}}$ levels with biodiesel operation. Engine with LHR combustion chamber with biodiesel increased $\mathrm{NO}_{\mathrm{x}}$ levels at full load operation by $44 \%$ at $27^{\circ} \mathrm{bTDC}$, in comparison with CE at $27^{\circ} \mathrm{bTDC}$. Increase of combustion temperatures with the faster combustion and improved heat release rates caused higher $\mathrm{NO}_{\mathrm{x}}$ levels in the engine with LHR combustion chamber in comparison with CE with biodiesel operation.

Table. 3 shows exhaust emissions at full load with test fuels. Decreasing the fuel density tends to increase spray dispersion and spray penetration. Particulate emissions at full load decreased with preheating of biodiesel in both versions of the combustion chamber, as seen in Table.3. The factors responsible for reduction of particulate emissions with preheated biodiesel might be i) the reduction of density of the biodiesel, as density is directly related to particulate emissions, ii) the reduction of the diffusion combustion proportion with the preheated biodiesel, iii) the reduction of the viscosity of the biodiesel, with which the fuel spray does not impinge on the combustion chamber walls of lower temperatures rather than it is directed into the combustion chamber.

From Table.3. it is noticed that particulate emissions at full load reduced with an increase of injector opening pressure in both versions of the combustion chamber, with different operating conditions of the biodiesel. Higher fuel injection pressures improved fuel-air mixing 
followed by faster combustion which directly influences pollutant formation leading to reduce particulate emissions. At higher injector opening pressure, particulate emissions in the exhaust reduced due to relatively superior fuel-air mixing. An increase in fuel injection pressure induces improvement in spray atomization, combustion and particulate emissions. Similar observations were reported by earlier studies. [14] [15] [28]. From Table.3, it is noticed that $\mathrm{NO}_{\mathrm{x}}$ levels reduced with preheating of the biodiesel. The change of the properties of viscosity and surface tension of fuel with preheating may lead to different relative duration of premixed and diffusive combustion regimes, which have different emission formation characteristics. As fuel temperature was increased, there was an improvement in the ignition quality, which will cause shortening of ignition delay. A short ignition delay period lowers the peak combustion temperature which suppresses $\mathrm{NO}_{\mathrm{x}}$ formation. From Table.3, it is noted that $\mathrm{NO}_{\mathrm{x}}$ levels increased in CE, while decreasing them in engine with LHR combustion chamber with different operating conditions of biodiesel with an increase of injector opening pressure. Enhanced spray characteristics, thus improving fuel air mixture preparation and evaporation process in $\mathrm{CE}$ might have increased gas temperatures with $\mathrm{CE}$, which increased $\mathrm{NO}_{\mathrm{x}}$ levels. Improved combustion with improved oxygen-fuel ratios in engine with LHR combustion chamber reduced $\mathrm{NO}_{\mathrm{x}}$ levels.

Table 3 Comparative data on Particulate Emissions \& $\mathrm{NO}_{\mathrm{x}}$ Levels at full load operation

\begin{tabular}{|c|c|c|c|c|c|c|c|c|c|}
\hline \multirow[t]{4}{*}{$\begin{array}{l}\text { Engine } \\
\text { Version }\end{array}$} & \multirow[t]{4}{*}{ Test fuel } & \multicolumn{4}{|c|}{$\begin{array}{l}\text { Particulate } \\
\text { emissions (Hartridge } \\
\text { Smoke Unit) }\end{array}$} & \multicolumn{4}{|c|}{ NO $_{\mathbf{x}}$ levels(ppm) } \\
\hline & & \multicolumn{4}{|c|}{ Injector opening pressure (bar) } & \multicolumn{4}{|c|}{ Injector opening pressure (bar) } \\
\hline & & \multicolumn{2}{|c|}{190} & \multicolumn{2}{|c|}{270} & \multicolumn{2}{|r|}{$\begin{array}{c}19 \\
0\end{array}$} & \multicolumn{2}{|c|}{270} \\
\hline & & NT & PT & NT & $\mathrm{PT}$ & NT & PT & NT & PT \\
\hline \multirow[t]{2}{*}{ (CE) } & $\mathrm{DF}$ & 48 & -- & 34 & -- & 850 & - & 950 & - \\
\hline & BD & 45 & 40 & 35 & 30 & 900 & 850 & 1000 & 950 \\
\hline \multirow[t]{2}{*}{ (LHR) } & DF & 60 & --- & 50 & --- & 1200 & -- & 1100 & - \\
\hline & $\mathrm{BD}$ & 40 & 35 & 30 & 25 & 1300 & 1250 & 1200 & 1150 \\
\hline
\end{tabular}

$\mathrm{CE}=$ Conventional engine, $\mathrm{LHR}-$ Low heat rejection engine. $\mathrm{DF}=$ Diesel fuel, $\mathrm{BD}=$ Biodiesel, NT=Normal temperature, $\mathrm{PT}=$ Preheated temperature

\section{CONCLUSIONS}

1. Engine with LHR combustion chamber is efficient for alternative fuel like biodiesel rather than neat diesel.

2. Engine with LHR combustion chamber with biodiesel improved its performance over CE at recommended injectiontiming.

3. The exhaust emissions improved with increase of injector opening pressure and with preheating with both versions of the combustion chamber with biodiesel.

\subsection{Future Scope of Work}

Engine with LHR combustion chamber gave higher $\mathrm{NO}_{\mathrm{x}}$ levels, which can be controlled by means of the selective catalytic reduction (SCR) technique using lanthanum ion exchanged zeolite (catalyst-A) and urea infused lanthanum ion exchanged zeolite (catalyst-B) with different versions of combustion chamber at full load operation of the engine [30]. 


\section{ACKNOWLEDGMENTS}

Authors thank authorities of Chaitanya Bharathi Institute of Technology, Hyderabad for providing facilities for carrying out this research work. Financial assistance provided by All India Council for Technical Education (AICTE), New Delhi is greatly acknowledged.

\section{REFERENCES}

[1] S.K. Acharya, R.K. Swain and M.K. Mohanti, The use of rice bran oil as a fuel for a small horse-power diesel engine. Energy Sources, Part A: Recovery, Utilization, and Environmental Effects, vol.33, no.1, pp 80-88, 2009.

[2] B.K. Venkanna, C. Venkataramana Reddy, B. Swati and Wadawadagi, Performance, emission and combustion characteristics of direct injection diesel engine running on rice bran oil / diesel fuel blend. International Journal of Chemical and Biological Engineering, vol.2, no.3, pp131-137, 2009.

[3] R.D. Misra and M.S. Murthy, Straight vegetable oils usage in a compression ignition engineA review. Renewable and Sustainable Energy Reviews, vol. 14,pp 3005-3013, 2010.

[4] No. Soo-Young, Inedible vegetable oils and their derivatives for alternative diesel fuels in CI engines: A review. Renew Sustain Energy Rev, vol.15, pp 131-149, 2011.

[5] Avinash Kumar Agarwal and Atul Dhar, Experimental investigations of performance, emission and combustion characteristics of Karanja oil blends fuelled DICI engine, Renewable Energy, vol. 52, pp 283-291, 2013.

[6] C.D. Rakopoulos, D.C. Rakopoulos, D.T. Hountalas et al., Performance and emissions of bus engine using blends of diesel fuel with biodiesel of sunflower or cottonseed oils derived from Greek feedstock, Fuel, vol.87: pp 147-157, 2008.

[7] P.M. McCarthy, M.G. Rasul and S. Moazzem, Analysis and comparison of performance and emissions of an internal combustion engine fuelled with petroleum diesel and different biodiesels, Fuel, vol. 90, pp 2147-2157, 2011.

[8] Anirudh Gautam and Avinash Kumar Agarwal, Experimental investigations of comparative performance, emission and combustion characteristics of a cottonseed biodiesel fueled four-stroke locomotive diesel engine, Int J Engine Res, vol. 14, pp354-370, 2013.

[9] Maddali Krishna and R. Chowdary, Comparative studies on performance evaluation of waste fried vegetable oil in crude form and biodiesel form in conventional diesel engine, SAE Paper 2014-01-1947, 2014.

[10] N. Durga Prasada Rao, M.V.S. Murali Krishna, , B. Anjeneya Prasad and P.V.K. Murthy. Effect of injector opening pressure and injectiontiming on exhaust emissions and combustion characteristics of rice bran oil in crude form and biodiesel form in direct injection diesel engine. IOSR Journal of Engineering, vol.4,no.2, pp 9-19, 2014.

[11] M. Pugazhvadivu and K. Jayachandran, Investigations on the performance and exhaust emissions of a diesel engine using preheated waste frying oil as fuel, Renew energy, vol. 30, no.14, pp 2189-2202, 2005.

[12] D. Agarwal and A.K. Agarwal, Performance and emissions characteristics of jatropha oil preheated and blends in a direct injection compression ignition engine, Appl. Therm. Eng, vol. 27, no.13, pp 2314-2323, 2007.

[13] Hanbey Hazar and Huseyin Aydin, Performance and emission evaluation of a CI engine fueled with preheated raw rapeseed oil (RRO)- diesel blends, Applied Energy, vol. 87, pp 786-790, 2007.

[14] I. Celikten, An experimental investigation of the effect of the injection pressure on engine performance and exhaust emission in indirectinjection diesel engines, Appl Therm Eng, vol. 23, pp 2051-60, 2003. 
[15] Avinash Kumar Agarwal, Dhananjay Kumar Srivastava, Atul Dhar, et al., Effect of fuel injection timing and pressure on combustion, emissions and performance characteristics of a single cylinder diesel engine, Fuel vol. 111, pp 374-83, 2013.

[16] P.V. Krishna Murthy, Studies on biodiesel with low heat rejection diesel engine. PhD Thesis, J. N. T. University, Hyderabad, 2010.

[17] T. Ratna Reddy, M.V.S. Murali Krishna, Ch. Kesava Reddy and P.V.K. Murthy, Performance evaluation of a low heat rejection diesel engine with mohr oil based biodiesel, British Journal of Applied Science \& Technology, vol. 2, no.2, pp 179-198, 2012.

[18] N. Janardhan, P. Ushasri, M.V.S. Murali Krishna and P.V.K. Murthy, Performance of biodiesel in low heat rejection diesel engine with catalytic converter. International Journal of Engineering and Advanced Technology, vol. 2, no.2, pp 97-109, 2012.

[19] N. Venkateswara Rao, M.V.S. Murali Krishna and P.V.K. Murthy, Effect of injector opening pressure and injection timing on exhaust emissions and combustion characteristics of high grade low heat rejection diesel engine with tobacco seed oil based biodiesel, Int J Recent Technol Eng 13; vol.2, no.4, pp 70-79, 2013.

[20] N. Venkateswara Rao M.V.S. Murali Krishna and P.V.K. Murthy, Effect of injector opening pressure and injection timing on performance parameters of high grade low heat rejection diesel engine with tobacco seed oil based biodiesel, Int J Current Eng \& Tech, vol.3, no.4, pp 1401$1411,2013$.

[21] M.V.S. Murali Krishna, N. Durga Prasada Rao, B. Anjenaya Prasad, Comparative studies on exhaust emissions and combustion characteristic of direct injection diesel engine with different combustion chamber with rice bran oil based biodiesel, Int J Eng Innovative Technol, vol.3, no.6, pp 163-173,2013,

[22] B. Subba Rao, E. Ramjee, P.V.K. Murthy and M.V.S.Murali Krishna, Studies on exhaust emissions and combustion characteristics of tobacco seed oil in crude form and biodiesel from a high grade low heat rejection diesel engine, International Journal of Industrial Engineering and Technology, vol.3, no.1, pp 27-36, 2013.

[23] M.V.S. Murali Krishna, N. Janardhan, Ch. Kesava Reddy, and P.V. Krishna Murthy, Experimental investigations on DI diesel engine with different combustion chambers, British Journal of Applied Science \& Technology, vol.6, no.3, pp239-260,2014.

[24] M.V.S. Murali Krishna, Performance evaluation of low heat rejection diesel engine with alternative fuels, PhD Thesis, J. N. T. University, Hyderabad, India, 2004.

[25] M.H. Fulekar, Chemical pollution - a threat to human life, Indian Journal of Environmental Technology, 1, pp 353-359, 1999.

[26] S.M. Khopkar, Environmental Pollution Analysis, [New Age International (P) Ltd, Publishers, New Delhi], pp 180-190, 2010.

[27] B.K. Sharma, Engineering Chemistry, [Pragathi Prakashan (P) Ltd, Meerut], pp 150-160, 2010.

[28] J.B. Heywood, Internal Combustion Engine Fundamentals, McGraw-Hill Book Company, New Delhi, 2013.

[29] P.V. Rao, Effect of properties of Karanja methyl ester on combustion and NOx emissions of a diesel engine. J Petroleum Tech \& Alternative Fuels, vol.2, no.5, pp 63-75, 2011.

[30] N. Janardhan, P. Usha Sri, M.V.S. Murali Krishna, Performance of biodiesel in low heat rejection diesel engine with catalytic converter, Int J Eng \& Advanced Tech 2012; vol.2, no.2, pp 97-109, 2012. 